\title{
Forced Marriage in Bangladesh: A Quantitative Study to Identify Key Factors
}

\author{
Mohammad Romel Bhuia1, Khalidur Rahman1, Khurshid Alam1, Lipi Akter Smrity2, \\ Md Kabir Hossain ${ }^{1}$ \\ ${ }^{1}$ Department of Statistics, Shahjalal University of Science and Technology, Sylhet, Bangladesh \\ ${ }^{2}$ Department of Applied Statistics, East West University, Dhaka, Bangladesh \\ Email: romel stat@yahoo.com, khalid sust@yahoo.com, smka bdstat@yahoo.com, smrity.sust@yahoo.com, \\ khossain-sta@sust.edu
}

Received 2 July 2015; accepted 18 August 2015; published 21 August 2015

Copyright (C) 2015 by authors and Scientific Research Publishing Inc.

This work is licensed under the Creative Commons Attribution International License (CC BY).

http://creativecommons.org/licenses/by/4.0/

(c) () Open Access

\begin{abstract}
In this article, a study on the status of forced marriages in Sylhet division of Bangladesh has been done to determine the prevailing state of it and to identify the key factors that needed to be emphasized. A survey was conducted and a total of 1369 respondents were interviewed. This study mainly deals with 146 respondents who were found to be forced to marriage and some of them were victims of it. Cross-table and multivariate logistic regression analyses were used to analyze the data. Results show that forced marriages and victims of such incidents are greatly affected by people's education and their income levels. The family types, age of participants, spouse selection approach, and desired time to marry are also significant factors. The concerned human rights workers should emphasize on the findings of this study to improve the human rights practice in Bangladesh.
\end{abstract}

Keywords

Forced Marriage, Human Rights, Marriage and Family

\section{Introduction}

A forced marriage is a marriage which is organized in such a way that at least one of the participants is married without his or her free and full consent. It differs from an arranged marriage, in which each participant provides his or her consent to a representative (such as a relative or friend) to select a spouse. The United Nations terms the forced marriage as a form of human rights violation, because it goes against the attitude of the liberty and freedom of individuals [1]. However, it remains in practice in different cultures and classes across the world, 
particularly among people living in and originating from South Asia and Africa.

A shotgun wedding is also considered as a forced marriage [2]. In such a case, one or both participants are forced into marriage to avoid embarrassment due to an unexpected pregnancy. Although the concept of shotgun wedding is no longer legal in the United States, a lot of unreliable stories and folk songs are examples of such coercion in the 18th and 19th centuries. In Japan, shotgun weddings mainly stem from contraception issues, the keenness to get pregnant in order to keep a partner and homosocial pressure to avoid the termination of the unexpected pregnancy [3]. Although the media have created a much higher level of awareness about forced marriage in the UK than ever before, a large number of women are annually subjected to forced marriage, either within the UK or during a visit to India, Bangladesh, or Pakistan under the guise of a vacation or visiting a sick relative [4]. During the Rouge regime, the people in Cambodia were forced to marry to increase the population to continue the revolution [5]. Sabbe et al. [6] found that four elements including the role of education and the economic factor influence the occurrence of child and forced marriage in Morocco. Thus, as a violation of human rights, forced marriage has become one of the grave issues in many countries, but it especially concerns for developing countries like Bangladesh.

In Bangladesh, although there is no specific law to ban forced marriages, legally, the consent of both participants to a marriage is required. In reality, forcing someone to marriage is prevalent and continues to be practiced unhesitatingly. Nevertheless, reliable statistics on forced marriages are not available in the usual sources of data of Bangladesh including Bangladesh Bureau of Statistics (BBS) [7] and Bangladesh Demographic and Health Survey (BDHS) [8] etc.

A survey on forced marriage was conducted in 2001 by Bangladesh National Women Lawyers Association in two districts of Bangladesh, namely, Joypurhat and Sylhet. In both districts, they came across extensive instances of forced marriages and Sylhet district was found as the most hazardous area (risky zone) of it. Thus, in this study, we also have conducted a survey on the people of Sylhet division, which, in addition to Sylhet, includes Maulvibazar, Sunamganj and Habiganj districts of Bangladesh. The purposes of the study are to find the descriptive statistics of forced marriage and to investigate the association of victim of forced marriage with various chosen factors. Finally, the study identifies the key factors influencing the case of victim of forced marriage in Sylhet division of Bangladesh. It is expected that the findings of this study might be utilized by the policy makers who are concerned with ensuring human rights in Bangladesh.

To our knowledge, there are only a few studies on the issue of forced marriages in Bangladesh. This study is a new endeavor in the content of identifying the key factors of victim of forced marriages based on statistical tools.

\section{Data Collection and Analysis}

\subsection{Study Locations}

The earlier study of Bangladesh National Women Lawyers Association [9] claimed that Sylhet is the most affected area of forced marriages. The studies in UK [10]-[13] indicated that there is a high propensity of forced marriages among the people who are originating from Bangladesh. Most of the migrated people of Bangladesh to UK are from Sylhet division [14]. Therefore, the focus of this study is on the status of forced marriages in Sylhet division of Bangladesh. The study has been conducted in ten Upazilas of Sylhet division namely: Sylhet Sadar, Balaganj, Beanibazar, Golapganj, Bishwanath, Rajnagar, Maulvibazar Sadar, Chhatak, Jagannathpur and Nabiganj.

\subsection{Data Collection}

A multi-stage cluster sampling procedure was used to collect the data. There are four districts in Sylhet division which are Sylhet, Moulvibazar, Sunamganj and Habiganj. Each district is divided into several Upazilas. In urban area, an Upazila is divided into wards and subsequently into mahallas within the wards. In rural area, an Upazila is divided into Union Parishads (UP) and then into Mouzas within the UPs. For the convenience of our survey, all Upazilas of the sylhet division were considered as primary sampling units (PSUs). There are 35 Upazilas in Sylhet division. At the first stage, we selected 10 Upazilas by using simple random sampling. At the second stage, a ward in the urban area and a union in the rural area were selected within each selected Upazila by using simple random sampling and such a ward or union was considered as a cluster. Since each of the entire union or 
ward was too large to be covered, we divided each union or ward into several compact segments based on total households. Finally, a compact segment was selected randomly from the selected clusters and all the households within the selected clusters were covered. A comprehensive household level interview questionnaire was used to collect information from ever-married women or men. A total of 1369 respondents were interviewed from the 10 selected areas. Out of them 146 respondents were found to be influenced at the time of marriage among which 46 branded themselves as a victim of forced marriage and labeled the incident as a human rights violation. This study mainly deals with those 146 respondents by dividing them into two categories according to victim of forced marriage or not.

\subsection{Study Variables}

Like many other demographic processes, nature of forced marriage is very complex and is governed by behavioral factors, which are themselves influenced by some socio-economic, demographic, cultural and proximate factors. Thus, the independent variables/factors were classified as the socio-economic variables, the demographic variables and the proximate variables. Each variable/factor within different classes was categorized into different groups according to their levels.

Socio-economic Variables: Education was categorized as illiterate and literate. Similarly, occupation as household activities and others that includes agriculture, business, job etc.; monthly income as lower income $(<8000$ Taka) and higher income ( $\geq 8000$ Taka); religion as Muslim and Non-Muslim; whether reads newspaper as "yes" and "no"; whether watches television or listen to radio as "yes" and "no"; decision on household matters as self-decision and other's decision; autonomy to mobility as restricted and unrestricted. While the variable district of residence was categorized Sylhet, Moulvibazar, Sunamganj, and Habiganj.

Demographic Variables: Sex was categorized as male and female. Similarly, marriage registration as "yes" and "no"; age at marriage as $\leq 21$ years and $>21$ years. The three categories of family type were unit, joint, and extended. The age of the respondents was categorized as 15 - 25 years, 25 - 35 years, 35 - 45 years, 45 - 55 years, and $>55$ years.

Proximate Variables: Spouse selection approach was categorized as parent's choice and other's choice (guardian, brother-sister, relatives); whereas desired time to marry was categorized as at that time and later.

The dependent variable was victim of forced marriage and it was categorized as "yes" and "no".

\subsection{Data Analysis}

Descriptive statistics for forced marriage were computed and categorized according to the chosen independent variables/factors. Bivariate cross-table analysis was used for examining the associations of selected factors with the victim of forced marriage. To provide further insight into the relationship, the independent variables/factors that had found significantly associated with victim of forced marriage were again studied by multivariate logistic regression analysis. Such analysis helped in identifying the key factors of victim of forced marriages.

\section{Results and Discussion}

\subsection{General Findings and Association of Factors with Victim of Forced Marriage and Discussion}

Table 1 shows the socio-economic differentials of respondents and associations with victim of forced marriage. In addition, some features of the observed facts have been presented in Figures 1-6. Among the total 146 respondents about half of them were from Sylhet district, 31.5 percent were illiterate, 52.1 percent were involved in household activities, 60 percent were belong to lower income group, 90.4 percent were Muslim, 76.2 percent did not read newspaper at least once in a weak, 48.6 percent did not watch television or listen to radio at least once in a weak, majority (87.9 percent) had no right to take decision on household matters, and 59.4 percent had no autonomy to mobility. Among the illiterate respondents, 43.5 percent were the victims of forced marriage. As compare to other professions (24.3 percent) the victims of forced marriage were high among the people who were involved in household activities (34.2 percent). Among the respondents belonging to higher income group, 14.0 percent were victims of forced marriage, while the parentage of victims increased to 37.3 percent if the respondents belonging to lower income group. The proportion of victims of forced marriage was 34.9 percent 


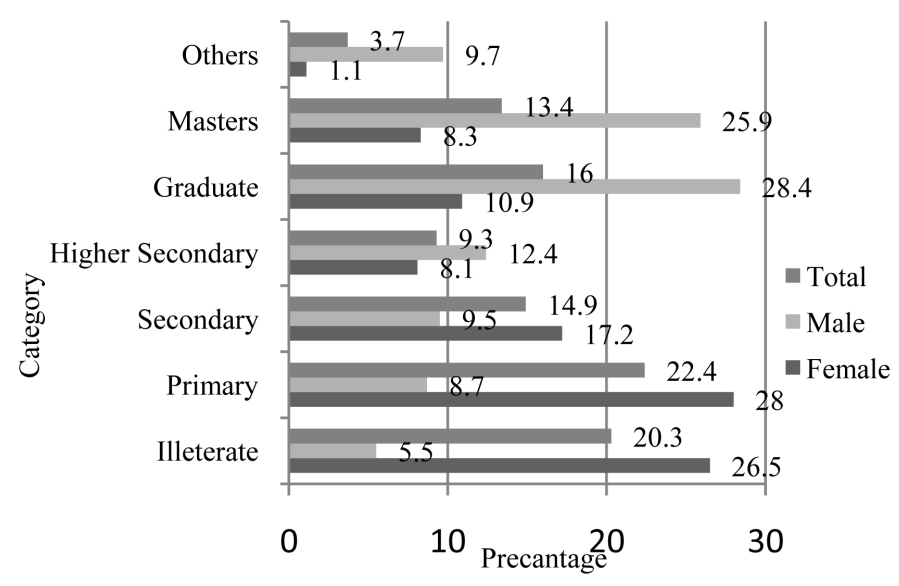

Figure 1. Distribution of respondents' education by sex.

Table 1. Distribution of respondents and association of socio-economic factors with victim of forced marriage.

\begin{tabular}{|c|c|c|c|c|c|c|c|}
\hline \multirow{3}{*}{ Socio-economic variables/factors } & \multirow{2}{*}{\multicolumn{2}{|c|}{ Respondents }} & \multicolumn{4}{|c|}{ Victim of forced marriage } & \multirow{3}{*}{$\begin{array}{c}\text { Value of } \\
\text { chi-square } \\
\chi^{2} \text { (d.f.) }\end{array}$} \\
\hline & & & \multicolumn{2}{|c|}{ Yes } & \multicolumn{2}{|c|}{ No } & \\
\hline & Number & $\%$ & Number & $\%$ & Number & $\%$ & \\
\hline \multicolumn{8}{|l|}{ Education of the respondents } \\
\hline Illiterate & 46 & 31.5 & 20 & 43.5 & 26 & 56.5 & \multirow[t]{2}{*}{$\chi_{(1)}^{2}=6.36^{\mathrm{a}}$} \\
\hline Literate & 100 & 68.5 & 23 & 23.0 & 77 & 77.0 & \\
\hline \multicolumn{8}{|l|}{ Occupation of the respondents } \\
\hline Household activities & 76 & 52.1 & 26 & 34.2 & 50 & 65.8 & \multirow{2}{*}{$\chi_{(1)}^{2}=1.73$} \\
\hline Others (Agriculture, business, & 70 & 47.9 & 17 & 24.3 & 53 & 75.7 & \\
\hline \multicolumn{8}{|l|}{ Monthly income of the family } \\
\hline Lower income ( $<8000$ Taka) & 75 & 60.0 & 28 & 37.3 & 47 & 62.7 & \multirow[t]{2}{*}{$\chi_{(1)}^{2}=8.10^{\mathrm{a}}$} \\
\hline Higher income ( $\geq 8000$ Taka) & 50 & 40.0 & 7 & 14.0 & 43 & 86.0 & \\
\hline \multicolumn{8}{|l|}{ Religion } \\
\hline Muslim & 132 & 90.4 & 39 & 29.5 & 93 & 70.5 & \multirow{2}{*}{$\chi_{(1)}^{2}=0.006$} \\
\hline Non Muslim & 14 & 9.6 & 4 & 28.6 & 10 & 71.4 & \\
\hline \multirow{2}{*}{\multicolumn{8}{|c|}{$\begin{array}{l}\text { Exposure to mass media } \\
\text { Reads newspapers at least once in a week }\end{array}$}} \\
\hline & & & & & & & \multirow{3}{*}{$\chi_{(1)}^{2}=5.01^{\mathrm{b}}$} \\
\hline Yes & 34 & 23.8 & 5 & 14.7 & 29 & 85.3 & \\
\hline No & 109 & 76.2 & 38 & 34.9 & 71 & 65.1 & \\
\hline \multicolumn{8}{|l|}{$\begin{array}{l}\text { Watches television or listens to } \\
\text { radio at least once in a week }\end{array}$} \\
\hline Yes & 73 & 51.4 & 16 & 21.9 & 57 & 78.1 & \multirow{2}{*}{$\chi_{(1)}^{2}=4.23^{b}$} \\
\hline No & 69 & 48.6 & 26 & 37.7 & 43 & 62.3 & \\
\hline \multicolumn{8}{|l|}{ District of residence } \\
\hline Sylhet & 79 & 54.1 & 24 & 30.4 & 55 & 69.6 & \multirow{4}{*}{$\chi_{(3)}^{2}=4.03$} \\
\hline Maulvibazar & 37 & 25.3 & 8 & 21.6 & 29 & 78.4 & \\
\hline Sunamganj & 27 & 18.5 & 11 & 40.7 & 16 & 59.3 & \\
\hline Habiganj & 3 & 2.1 & 0 & 00.0 & 3 & 100 & \\
\hline \multicolumn{8}{|l|}{ Decision on household matters } \\
\hline Self-decision & 17 & 12.1 & 5 & 29.4 & 12 & 70.6 & \multirow[t]{2}{*}{$\chi_{(1)}^{2}=0.007$} \\
\hline Other's decision & 123 & 87.9 & 35 & 28.5 & 88 & 71.5 & \\
\hline \multicolumn{8}{|l|}{ Autonomy to mobility } \\
\hline Restricted & 82 & 59.4 & 27 & 32.9 & 55 & 67.1 & \multirow[t]{2}{*}{$\chi_{(1)}^{2}=1.51$} \\
\hline Unrestricted & 56 & 40.6 & 13 & 23.2 & 43 & 76.8 & \\
\hline
\end{tabular}

${ }^{\mathrm{a} S i g n i f i c a n c e ~ P r o b a b i l i t y, ~} P<0.01$; ${ }^{\mathrm{b}}$ Significance Probability, $P<0.05$; d.f. $=$ degrees of freedom. Note: Total respondents may not be exact figure due to non-response and not applicable. 


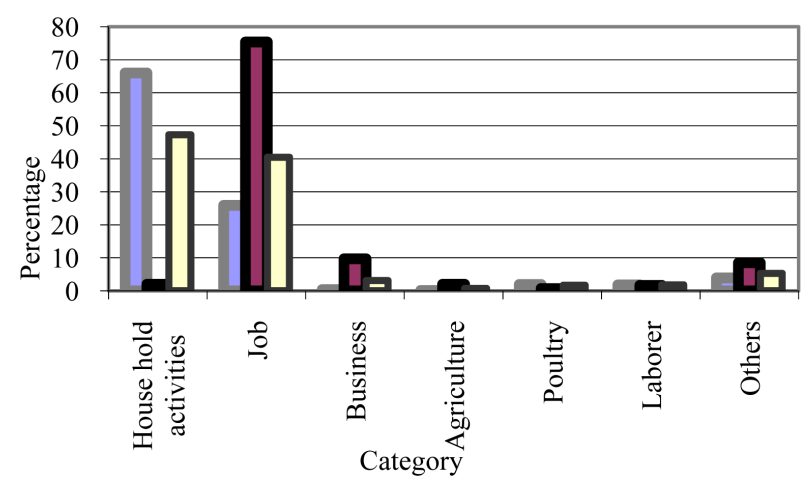

Gemale $\mathbf{\square}$ Male $\mathbf{\square}$ Total

Figure 2. Distribution of respondents’ occupation by sex.

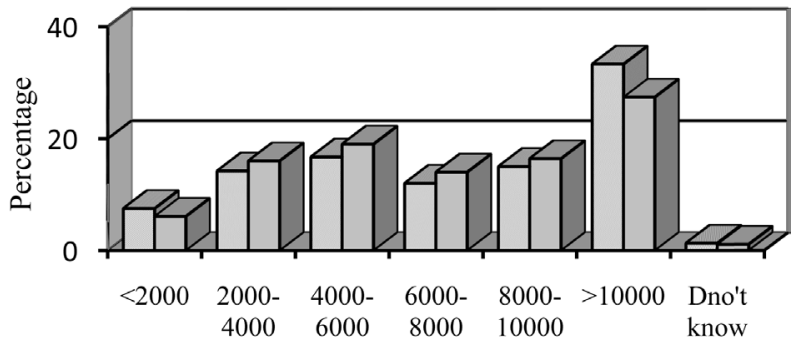

QMonthly income $\quad$ Monthly expenditure

Figure 3. Distribution of respondents by income and expenditure.

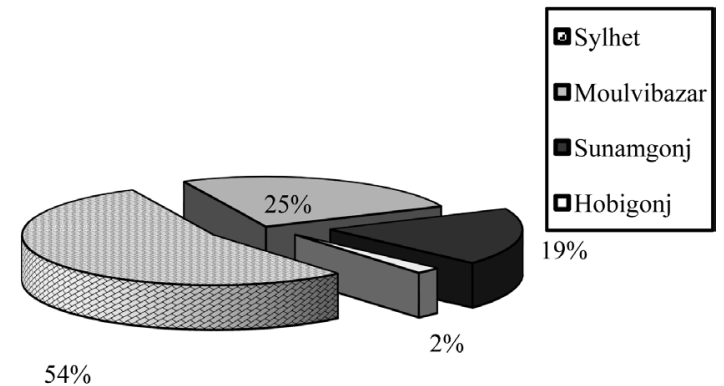

Figure 4. Distribution of respondents by the district of resident.

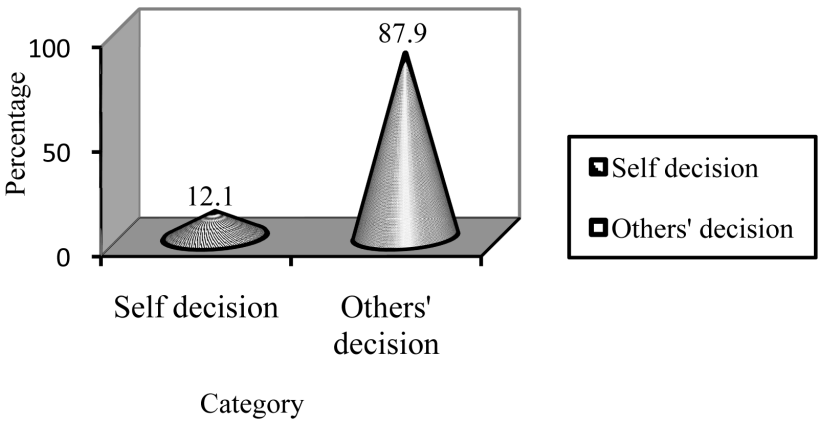

Figure 5. Distribution of respondents by decision capacity in house hold matters. 




Category

Figure 6. Distribution of respondents by mobility status.

for those who had not read newspaper and it declined to 14.7 percent for those who had read newspaper at least once in a week. Similarly, among the respondents who had not watched television or had not listened radio, 37.7 percent were victims of marriage, while this figure turned down to 21.9 percent if they had watched television or listened to radio at least once in a week. Highest percentage of victims of forced marriage was prevailing in Sunamganj district (40.7 percent), followed by Sylhet district (30.4 percent) and Moulvibazar district (21.6 percent). The lowest level of victims of forced marriage was found in Habiganj district, that is, no victim of forced marriage had been found in this district. About 29 percent were the victims of forced marriage in the both groups of the factor decision on household matters. Respondents, whose mobility was restricted, had been victims of forced marriage at a rate of about 33 percent and the rate was decreased to about 23 percent if the respondents were unrestricted to go outside. The findings show that victim of forced marriage is significantly associated with education $(P<0.01)$, income $(P<0.01)$ and less exposure to mass-media $(P<0.05)$.

Table 2 shows demographic differentials of respondents and associations with victim of forced marriage. In this study male-female ratio was 0.32 . Among the respondents 63 percent were from unit family and about 83 percent belonged to age more than 25 years. Mean and standard deviation (SD) of age were 37.47 years and 11.92 years, respectively. Mean age at marriage was about 21 years and about one fourth of the respondent's marriages were not registered. Incidence of victim of forced marriage was higher among female (32.4 percent) than that of male (20 percent). Highest percentage of forced marriage had been observed among the respondents of extended family (54.5 percent), followed by unit family (30.4 percent) and lowest in joint family (20.9 percent). The rate of victim of forced marriage decreases sharply with the increase of respondents' age. The percentage of victim of forced marriage was observed highest (51.9 percent) among the people belonging to age group 15-25, followed by the age group 25 - 35 (28.6 percent), and lowest (12.5 percent) for age greater than 55 years. Victim of forced marriage rate observed higher (34 percent) for the people whose age at marriage was less than 21 years. About 37 percent of registered marriages produced victims of forced marriage; whereas for the unregistered marriages it was about 27 percent. Table 2 also shows that the victim of forced marriage is significantly associated with family type $(P<0.1)$ and age of respondents $(P<0.05)$.

Differentials of respondents according to proximate factors and associations with victim of forced marriage have been presented in Table 3. It is seen that 77.5 percent marriages were held by parent's choice and 61.2 percent desired to take more time to marry. Proportion of victims of forced marriage is lower (25.2 percent) among the respondents who married according to parents' choice and higher (48.4 percent) if one married according to others' choice such as guardian, brother-sister, relatives etc. Percentage of victims of forced marriage was low (14.8 percent) for those whose spouses were selected by their parents. Table 3 also indicates that victim of forced marriage is significantly associated with spouse selection approach $(P<0.05)$ and desired time for marriage $(P<0.01)$.

From the previous tables we find that majority of the respondents of this study were female, Muslim and they depend on others for household matters. Average literacy rate (68.5 percent) was found higher than that (59.82 percent) which was estimated by BBS [7]. The average family income (Tk. 7816) represents better economic condition of the people of Sylhet division as compared to other parts of the country. Although education and higher income level generally motivate people to new ideas, such as moving to a new place or taking a job out- 
Table 2. Distribution of respondents and association of demographic factors with victim of forced marriage.

\begin{tabular}{|c|c|c|c|c|c|c|c|}
\hline \multirow{3}{*}{ Demographic variables/factors } & \multirow{2}{*}{\multicolumn{2}{|c|}{ Respondents }} & \multicolumn{4}{|c|}{ Victim of forced marriage } & \multirow{3}{*}{$\begin{array}{c}\text { Value of } \\
\text { chi-square } \\
\chi_{\text {(d.f.) }}^{2}\end{array}$} \\
\hline & & & \multicolumn{2}{|c|}{ Yes } & \multicolumn{2}{|c|}{ No } & \\
\hline & Number & $\%$ & Number & $\%$ & Number & $\%$ & \\
\hline \multicolumn{8}{|l|}{ Sex of the respondents } \\
\hline Male & 35 & 24.0 & 7 & 20.0 & 28 & 80.0 & $\chi_{(1)}^{2}=1.98$ \\
\hline Female & 111 & 76.0 & 36 & 32.4 & 75 & 67.6 & \\
\hline \multicolumn{8}{|l|}{ Family Type } \\
\hline Unit family & 92 & 63.0 & 28 & 30.4 & 64 & 69.6 & \\
\hline Joint family & 43 & 29.5 & 9 & 20.9 & 34 & 79.1 & $\chi_{(2)}^{\prime}=4.88$ \\
\hline Extended family & 11 & 7.5 & 6 & 54.5 & 5 & 45.5 & \\
\hline \multicolumn{8}{|l|}{ Age of the respondents } \\
\hline $15-25$ & 27 & 18.8 & 14 & 51.9 & 13 & 48.1 & \\
\hline $25-35$ & 42 & 29.2 & 12 & 28.6 & 30 & 71.4 & \\
\hline $35-45$ & 41 & 28.5 & 10 & 24.4 & 31 & 75.6 & $\chi_{(4)}^{2}=9.76^{\mathrm{t}}$ \\
\hline $45-55$ & 18 & 12.5 & 4 & 22.2 & 14 & 77.8 & \\
\hline$\geq 55$ & 16 & 11.1 & 2 & 12.5 & 14 & 87.5 & \\
\hline \multicolumn{8}{|l|}{ Mean \pm SD: $37.47 \pm 11.92$} \\
\hline \multicolumn{8}{|l|}{ Age at marriage } \\
\hline$\leq 21$ years (mean age at marriage) & 94 & 65.7 & 32 & 34.0 & 62 & 66.0 & $\chi_{(1)}^{2}=2.87$ \\
\hline$>21$ years (mean age at marriage) & 49 & 34.3 & 10 & 20.4 & 39 & 79.6 & \\
\hline Mean \pm SD: $21.05 \pm 6.26$ & & & & & & & \\
\hline \multicolumn{8}{|l|}{ Marriage registration } \\
\hline Yes & 101 & 75.4 & 27 & 26.7 & 74 & 73.3 & $\chi_{(1)}^{2}=1.12$ \\
\hline No & 33 & 24.6 & 12 & 36.4 & 21 & 63.6 & \\
\hline
\end{tabular}

${ }^{\mathrm{a}}$ Significance Probability, $P<0.1$; ${ }^{\mathrm{b}}$ Significance Probability, $P<0.05$; d.f. $=$ degrees of freedom. Note: Total respondents may not be exact figure due to non-response and not applicable.

Table 3. Distribution of respondents and association of proximate factors with victim of forced marriage.

\begin{tabular}{|c|c|c|c|c|c|c|c|}
\hline \multirow{3}{*}{ Proximate variables/factors } & \multirow{2}{*}{\multicolumn{2}{|c|}{ Respondents }} & \multicolumn{4}{|c|}{ Victim of forced marriage } & \multirow{3}{*}{$\begin{array}{c}\text { Value of } \\
\text { chi-square } \\
\chi_{\text {(d.f.) }}^{2}\end{array}$} \\
\hline & & & \multicolumn{2}{|c|}{ Yes } & \multicolumn{2}{|c|}{ No } & \\
\hline & Number & $\%$ & Number & $\%$ & Number & $\%$ & \\
\hline \multicolumn{8}{|l|}{ Spouse selection approach } \\
\hline Parents choice & 107 & 77.5 & 27 & 25.2 & 80 & 74.8 & $\chi_{(1)}^{2}=6.09^{b}$ \\
\hline Others' choice (guardian, brother-sister, relatives) & 31 & 22.5 & 15 & 48.4 & 16 & 51.6 & \\
\hline \multicolumn{8}{|l|}{ Desired time to marry } \\
\hline Desired to marry at that time & 54 & 38.8 & 8 & 14.8 & 46 & 85.2 & $\chi_{(1)}^{2}=8.40^{\mathrm{a}}$ \\
\hline Desired to take more time to marry & 85 & 61.2 & 32 & 37.6 & 53 & 62.4 & \\
\hline
\end{tabular}

${ }^{\mathrm{a}}$ Significance Probability, $P<0.01$; ${ }^{\mathrm{b}}$ Significance Probability, $P<0.05$; d.f. = degrees of freedom. Note: Total respondents may not be exact figure due to non-response and not applicable.

side the home, it is unfortunate that in Sylhet community half of the respondents were involved with household activities. This may be due to more dependency on foreign remittance. A considerable portion of the people in the study area is living in the foreign countries including UK, USA. The guardians have a tendency to select a bridegroom whose family or he is financially sound. Thus, ignoring the personal choice, the female persons are usually compelled to marry a selected bridegroom who usually lives or stays in abroad. Educated and pretty girls and women are more vulnerable to be exploited in forced marriage with bridegrooms from UK, USA. Such practices might have produced higher percentage of female respondents and victims.

The tradition of arranged marriages has been operating successfully among the Muslims. They do not consider love marriages as the most appropriate way of finding a life-partner. Influencing bride or bridegroom at the time of marriage is the first step of forced marriage. The study found that the respondents were influenced during marriage and spouses of the most of them were selected by their parents. This is because the Muslim women are usually obedient to parents and they are bounded to follow the decisions made by other family members.

Mean age at marriage for female and male were 18.55 years and 28 years with standard deviation 4.66 and 4.64, respectively. About one sixth of the women were married before 15 years, which indicates the existence of high rate of early marriage. One fourth of the respondents reported that their marriages were not registered 
which agrees with the report of BDHS [8]. The study also found that the respondents who were unable to read newspapers regularly were highly exposed to forced marriage.

Lack of education is always an important factor in all social problems. Education should have substantial effect on the victim of forced marriage. In principle, the association of education with the victim of forced marriage is usually negative and is determined by the level of educational attainment. According to our findings, education and income are the most important determinants of the victim of forced marriage and significantly associated with it. Forced marriage mostly occurs among the people of poor community and they are more likely to be victim of it. Family type also significantly affects the occurrence of forced marriage. As the extended families have huge number of members, female spouse is likely to be humiliated by others in different forms. As a result, the person belongs to an extended family is the most affected of forced marriage. With the increase of age coercion decreased. Hence, age of the respondents was found as a significant factor of the victim of forced marriage. Desired time to marry and the spouse selection approach were also found as significant determinants of the victim of forced marriage. Victims of forced marriage were higher among the respondents who desired to take more time to marry and whose spouse was selected by other than parents. Victims of forced marriage were lower to the people who regularly read newspaper and watched television or listened to radio.

\subsection{Logistic Regression Analysis}

Now the significant associations that observed in the cross-table analyses will be discussed in terms of logistic regression analysis. All of the considered factors were assumed to be uncorrelated with each other. Table 4 summarizes the corresponding results from logistic regression analysis.

Table 4. Logistic regression analysis (Dependent Variable: Victim of Forced Marriage).

\begin{tabular}{|c|c|c|}
\hline \multirow{2}{*}{ Variable/factor } & \multicolumn{2}{|c|}{ Regression coefficients } \\
\hline & Coefficient & Odds ratios \\
\hline \multicolumn{3}{|l|}{ Education of the respondents } \\
\hline Illiterate $^{\mathrm{RC}}$ & - & 1.00 \\
\hline Literate & $-0.845^{\mathrm{c}}$ & 0.430 \\
\hline \multicolumn{3}{|l|}{ Monthly income of the family } \\
\hline$\leq 8000$ Taka (lower income) ${ }^{\mathrm{RC}}$ & - & 1.00 \\
\hline >8000 Taka (higher income) & $-1.439^{b}$ & 0.237 \\
\hline \multicolumn{3}{|l|}{ Reads newspaper at least once in a week } \\
\hline $\mathrm{No}^{\mathrm{RC}}$ & - & 1.00 \\
\hline Yes & -0.076 & 0.927 \\
\hline \multicolumn{3}{|c|}{ Watches television or listens to radio at least once in a week } \\
\hline $\mathrm{No}^{\mathrm{RC}}$ & - & 1.00 \\
\hline Yes & -0.249 & 0.780 \\
\hline \multicolumn{3}{|l|}{ Family type } \\
\hline Unit family $^{\mathrm{RC}}$ & - & 1.00 \\
\hline Joint family & -0.348 & 0.706 \\
\hline Extended family & $1.365^{\mathrm{c}}$ & 3.917 \\
\hline \multicolumn{3}{|l|}{ Age of the respondents } \\
\hline $15-25$ Years $^{\mathrm{RC}}$ & - & 1.00 \\
\hline $25-35$ Years & -0.782 & 0.457 \\
\hline $35-45$ Years & $-1.484^{\mathrm{b}}$ & 0.227 \\
\hline 45 - 55 Years & $-1.364^{\mathrm{c}}$ & 0.256 \\
\hline$\geq 55$ Years & $-3.193^{\mathrm{a}}$ & 0.041 \\
\hline \multicolumn{3}{|l|}{ Spouse selection approach } \\
\hline Parents' choice ${ }^{\mathrm{RC}}$ & - & 1.00 \\
\hline Others’ choice & $1.230^{\mathrm{c}}$ & 3.421 \\
\hline \multicolumn{3}{|l|}{ Desired time to marry } \\
\hline At that time ${ }^{\mathrm{RC}}$ & - & 1.00 \\
\hline Later & $1.191^{\mathrm{b}}$ & 3.290 \\
\hline Constant & \multicolumn{2}{|c|}{-0.206} \\
\hline -2 log likelihood significance & \multicolumn{2}{|c|}{133.506} \\
\hline
\end{tabular}

${ }^{\mathrm{a}}$ Significance Probability, $P<0.01$; ${ }^{\mathrm{b}}$ Significance Probability, $P<0.05$; c. Significance Probability, $P<0.1$. RC $=$ Reference Category. 
Multivariate logistic regression analysis reconfirms that education is an important factor that affecting the victim of forced marriage. The risk of the victim of forced marriage was lower to the literate respondents. The corresponding odds ratio indicates that the educated respondents are less likely to be victim than those who had no education. Income is the key determinant of life style and influences almost all decisions of human life, including demographic and health behavior. The result from logistic regression analysis also agrees that income is a very important factor and it has significant effect on the victim of forced marriage. If the family income is not sufficient, the poor people often try to marry off their daughters or sons to more affluent families and for this purpose they may force the participants into marriage. Thus, the odds ratio for income shows that the risk of forced marriage was 76 percent lower to the people of higher income group. Respondents who watched television or listened to radio at least once in a week were subjected to 22 percent lower in the risk of forced marriage than those who did not watch television or listen to radio at least once in a week. Such result also supports the similar finding in the previous section.

The risk of forced marriage for the person belonged to joint family was lower compared to that of unit family. The respondents of joint family were 29 percent less likely to be victimized by the forced marriage than those of unit family. On the other hand, the risk of victim was higher to the respondents of extended family compared to that of unit family. The respondents of extended family were 3.92 times more likely to be victimized by the forced marriage than that of unit family. This may be due to the fact that the guardians of extended families might treat their girls as a burden. This is why they often forced them into marriage. A decrease in the possibility of the victim of forced marriage has been observed to the respondents with the increase in their age. Age of respondents is also an important determinant of the victim of forced marriage. The respondents belonged to age group 25 - 35 years, 35 - 45 years, 45 - 55 years and $\geq 55$ years were 54 percent, 77 percent, 74 percent and 96 percent, respectively, and were found less likely to be victimized by the forced marriage compared to those of age group 15 - 25 years. This finding clearly indicates that the victim of forced marriage is directly related with early marriage. Spouse selection approach is another important factor that significantly affects the victim of forced marriage. From Table 4 it is also found that the respondents who married according to others' choice were 3.42 times more likely to be victimized by the forced marriage than those who married according to parents' choice. Coercion may take place on marriage when one desires to marry later. Odds ratio indicates that possibility of occurrence of the victim of forced marriage was higher (3.29 times) to those who wanted to marry later. Therefore, almost all the findings from logistic regression analysis strongly agreed with the findings in the cross-table analysis.

\section{Limitations}

It should be noted that, like other socio-economic studies, there were some limitations in this study. First, it was difficult to collect the reliable information regarding forced marriage from the victims and community people. For example, the victims of the forced marriage did not feel easy to disclose the matter. They hesitated to inform all of the matters because of fear, insecurity and prestige. Besides that there was limited opportunity to go to them and ask relevant questions about forced marriage. As a result, the study did not able to obtain a representative sample of victims of forced marriage. Second, there were some non-sampling errors that integrated in the study. Religious restriction was also a little bit problems to collect data in Sylhet division. There were some conservative people who expressed their discontent but most of the people were co-operated with the data collectors. Third, it should be noted that it was difficult to find whether the significant associations shown in the report were causal or due to cross-sectional data analysis. Information biases may be accrued in the cross-sectional study [15]. Moreover, there was short of relevant literature and past research reports in Bangladesh to get an overview of existing knowledge of forced marriage and to identify the gaps where the study could be focused.

\section{Conclusions}

The forced marriage practice in the society has drawn attention not only of the human rights workers and organizations but also of the policy makers and planners for the fact that prevention of such practice will help in the reduction of human rights violation, and gender discrimination. In this study, we evaluated the factors that are believed to have influences on marriage norms and also focused on the status of forced marriage in Sylhet division of Bangladesh. 
A survey on the people of Sylhet division was conducted to collect the relevant data on forced marriage. Data were analyzed in two steps to identify the main factors that influence forced marriage practice and the victim of it in the society. The study found that education and income level of the people should be improved to abolish the forced marriage practice from the society. It also suggested that awareness against the forced marriage can be developed by utilizing the mass media properly. The relevant laws that prevent the early marriages should be appropriately implemented. The lasting of extended family was not encouraged in the study. The study also pointed out that, if forced marriage is not avoidable, at least the spouse should be selected by the parents and the participants should have the ability to choose the time of marriage.

Finally, to minimize the victims of forced marriage, all the above findings should be materialized by the concerned human rights workers, organizations, policy makers, and planners. However, the role of mass media was not foreseen on the reduction of victims of forced marriage.

\section{Acknowledgements}

The authors express their profound acknowledgement to the authority of Newham Bengali Community Trust (NBCT), Sylhet, Bangladesh, for providing fund to collect data for this research work. Authors also would like to express their heartiest thanks to the students of the Dept. of Statistics, and Sociology of SUST who were engaged with this research for data collection.

\section{References}

[1] Universal Declaration of Human Rights. Article 16(2), United Nations.

[2] Wikipedia (2015) Shotgun Wedding. http://en.wikipedia.org/wiki/Shotgun_wedding

[3] Castro-Vázquez, G. (2015) Shotgun Weddings (Dekichatta Kekkon) in Contemporary Japan. Culture, Health \& Sexuality, 17, 747-762. http://dx.doi.org/10.1080/13691058.2015.1048528

[4] Keogh, P., Kazimirski, A., Purdon, S. and Maisey, R. (2013) Estimating the Prevalence of Forced Marriage in England. In: McCarthy, J.R., Gillies, V. and Hooper, C.-A., Eds., Family Troubles?: Exploring Changes and Challenges in the Family Lives of Children and Young People, Policy Press, Bristol, 245. http://dx.doi.org/10.1332/policypress/9781447304432.003.0020

[5] Jain, N. (2008) Forced Marriage as a Crime against Humanity Problems of Definition and Prosecution. Journal of International Criminal Justice, 6, 1013-1032. http://dx.doi.org/10.1093/jicj/mqn064

[6] Sabbe, A., Oulami, H., Zekraoui, W., et al. (2013) Determinants of Child and Forced Marriage in Morocco: Stakeholder Perspectives on Health, Policies and Human Rights. BMC International Health and Human Rights, 13, 43. http://dx.doi.org/10.1186/1472-698X-13-43

[7] BBS (2010) Bangladesh Literacy Survey. http://www.bbs.gov.bd/PageSearchContent.aspx?key=literacy

[8] BDHS (2004) Bangladesh Demographic and Health Survey. http://catalog.ihsn.org/index.php/catalog/134/related_citations

[9] Bangladesh National Women Lawyers Association (2001) Forced Marriages: A Blot in Women's Freedom of Expression. Bangladesh National Women Lawyers Association, Dhaka, 77.

[10] Anitha, S. and Gill, A. (2009) Coercion, Consent and the Forced Marriage Debate in the UK. Feminist Legal Studies, 17, 165-184. http://dx.doi.org/10.1007/s10691-009-9119-4

[11] Chantler, K., Gangoli, G. and Hester, M. (2009) Forced Marriage in the UK: Religious, Cultural, Economic or State Violence? Critical Social Policy, 29, 587-612. http://dx.doi.org/10.1177/0261018309341905

[12] Gill, A. and Mitra-Kahn, T. (2012) Modernising the Other: Assessing the Ideological Underpinnings of the Policy Discourse on Forced Marriage in the UK. Policy \& Politics, 40, 104-119. http://dx.doi.org/10.1332/147084411X581763

[13] Phillips, A. and Dustin, M. (2004) UK Initiatives on Forced Marriage: Regulation, Dialogue and Exit. Political Studies, 52, 531-551. http://dx.doi.org/10.1111/j.1467-9248.2004.00494.x

[14] Das, T.K. (2014) Migration of Sylhetis to the United Kingdom: an Exploration. Social Work Chronicle, 2, 69-86.

[15] Guo, X., et al. (2003) The Prevalence of Subjective Symptoms after Exposure to Arsenic in Drinking Water in Inner Mongolia, China. Journal of Epidemiology, 13, 211-215. 